\title{
Elhízó Magyarország. A túlsúly és az elhízás trendje és prevalenciája Magyarországon, 2015
}

\author{
Rurik Imre dr. ${ }^{1}$ - Ungvári Tímea ${ }^{1}$ - Szidor Judit dr. ${ }^{1}$ - Torzsa Péter dr. ${ }^{2}$ \\ Móczár Csaba dr. ${ }^{3}$ - Jancsó Zoltán dr. ${ }^{1}$ - Sándor János dr. ${ }^{4}$ \\ ${ }^{1}$ Debreceni Egyetem, Népegészségügyi Kar, Családorvosi és Foglalkozás-egészségügyi Tanszék, Debrecen \\ ${ }^{2}$ Semmelweis Egyetem, Általános Orvostudományi Kar, Családorvosi Tanszék, Budapest \\ ${ }^{3}$ Irinyi Háziorvosi Központ, Kecskemét \\ ${ }^{4}$ Debreceni Egyetem, Népegészségügyi Kar, Megelőző Orvostani Intézet, \\ Epidemiológiai és Biostatisztikai Tanszék, Debrecen
}

Bevezetés: A világszerte növekvő arányú elhízás Magyarországon is észlelhető, populációs előfordulásáról az első nagyszabású felmérés 1988-ban történt. Célkitüzés: A szerző́k az eddigi legnagyobb esetszámú hazai elhízásprevalenciavizsgálataik eredményeit mutatják be, amelyet háziorvosok és foglalkozás-egészségügyi orvosok részvételével bonyolítottak le. Módszer: A 18 év fölötti magyar lakosság 0,55\%-ának, 43287 fö (17 901 férfi és 25386 nő) regisztrált adatait elemezték, országosan reprezentatív megoszlásban. Összehasonlították a korábbi hazai vizsgálatokkal, elemezték a testtömegindex, haskörfogat, iskolázottság, hypertonia és/vagy diabetes jelenléte és az életkor közötti kapcsolatot. Eredmények: Összességében férfiaknál a túlsúly 40\%, az elhízás 32\%-ban van jelen, míg nőknél mindkét kategória közel 32\%-ban. A 18-34 év közötti életkori csoportban a férfiak 32,7\%-a túlsúlyos, míg 18,2\%-uk elhízott, 35-59 év között 40,1\% és 34,4\%, 60 év fölött 43,5\%, illetve 38,8\%. Ugyanezen korosztályi adatok nőknél: 19,6 és $15,7 \%, 36,8$ és $38,7 \%, 36,5$ és 39,7\%. A testtömegindex-eloszlásokat és a hasi elhízás (férfiaknál >102 cm, nőknél >88 $\mathrm{cm}$ ) adatait évtizedes életkori csoportokban és településtípusok szerint is bemutatják. A legnagyobb arányú túlsúly a felsőfokú végzettségű férfiaknál, a legtöbb elhízott a legalacsonyabb végzettségű nőknél volt. A testtömegindex szerinti és hasi elhízás a falvakban volt a legnagyobb arányú, különösen nőknél. A metabolikus betegségek jelenléte erősen korrelált a testtömegindexszel, és inverz módon az urbanizáció mértékével. Következtetések: Az elmúlt évtizedekben a túlsúly és fôleg az elhízás aránya jelentősen megnőtt, különösen látványosan férfiaknál, szembetűnően a fiatalabbaknál. Ez nemcsak orvosi, de komoly népegészségügyi és gazdasági problémát is jelent, kezelése össztársadalmi figyelmet, a jelenleginél nagyobb szakmapolitikai támogatást igényel. Orv. Hetil., 2016, 157(31), 1248-1255.

Kulcsszavak: diabetes, elhízás, hypertonia, Magyarország, népegészségügy, prevalencia, túlsúly

\section{Obese Hungary. Trend and prevalence of overweight and obesity in Hungary, 2015}

Introduction: The prevalence of obesity is growing continuously worldwide, even in Hungary. Since 1988, when the first professional wide-range evaluation was performed, only limited data are available. Aim: Authors present the results of the ever largest Hungarian obesity-prevalence surveys, performed by family and occupational physicians. Method: Data from $0.55 \%$ of the population above 18 year were registered in all geographical regions of Hungary (43,287 persons; 17,901 males and 25,386 females), close to the proper national representativeness. Age, body mass index, waist circumference, educational level, presence of hypertension and/or diabetes were analyzed statistically and compared with previous data. Results: The overall prevalence rate of overweight and obesity among men was $40 \%$ and $32 \%$, respectively, while overweight and obesity occurred in $32 \%$ of women. In the different age groups of men, the prevalence of overweight and obesity was: $32.7 \%$ and $18.2 \%$ in $18-34$ years; $40.1 \%$ and $34.4 \%$ in $35-59$ years; $43.5 \%$ and $38.8 \%$ in over 60 years, respectively. In the same age groups of women, overweight and obesity occurred in $19.6 \%$ and $15.7 \%, 36.8 \%$ and $38.7 \%$, and $36.5 \%$ and $39.7 \%$, respectively. Body mass index and waist-circumference were presented according to age, by decades and by type of residency as well. The highest ratio of overweight was registered among men with the highest educational level, while highest ratio of obesity among women having the lowest education. Obesity according to Body mass index and abdominal obesity was the highest in the villages, espe- 
cially among females. Registered metabolic morbidities were strongly correlated with body mass index and both were inversely related to the level of urbanization. Conclusions: Over the previous decades, the ratio of the overweight and even the number of obese persons increased significantly, and it was most prominent among males, mainly in younger generation. Obesity means a serious medical, public health and economic problem, and it requires higher public awareness and political support.

Keywords: diabetes, Hungary, hypertension, obesity, overweight, prevalence, public health

Rurik, I., Ungvári, T., Szidor, J., Torzsa, P., Móczár, Cs., Jancsó, Z., Sándor, J. [Obese Hungary. Trend and prevalence of overweight and obesity in Hungary, 2015]. Orv. Hetil., 2016, 157(31), 1248-1255.

(Beérkezett: 2016. január 10.; elfogadva: 2016. május 18.)

\section{Rövidítések}

$\mathrm{BMI}=$ testtömegindex $; \mathrm{EH}$ = esélyhányados; $\mathrm{MT}=$ megbízha tósági tartományok; OÉTI = Országos Élelmezési és Táplálkozástudományi Intézet; OLEF = Országos Lakossági Egészség Felmérés

Az elhízás világjárványhoz hasonló (obesity pandemic), terjedése évtizedek óta megfigyelhető. Ez komoly egészségügyi és népegészségügyi problémát jelent a Föld legtöbb országában, főleg társbetegségeivel és szövődményeivel kapcsolatban, ami az elhízottak egészségügyi ellátását nehezebbé és költségesebbé teszi. Jelentős teher az egészségügyi ellátórendszerre és a gazdaságra, esetenként sok szociális probléma forrása is. A túlsúlyos és elhízott emberek nemcsak az utcákon és közterületeken láthatók egyre nagyobb arányban, hanem betegként a rendelőkben, kórházakban is.

Bár a jelenség világszerte megfigyelhető, vannak országok közötti, sőt országon belüli különbségek is. Az országok közötti eltéréseket társadalmaik eltérő fejlettsége, kultúrája és életszínvonala magyarázza [1]. Országon belül inkább a domborzati viszonyokkal találtak összefüggéseket: hegyes vidékeken alacsonyabb, síkságon, tengerek mellett nagyobb arányú az elhízás $[2,3]$.

Magyarországon az elhízás terjedésének felismerése, népegészségügyi jelentőségének értékelése később kezdődött, mint más országokban, az emelkedő trend azonban már a korábbi hazai felmérések során is észlelhető volt $[4-8]$.

$\mathrm{Az}$ antropometriai paraméterek meghatározása általában nem kötelező (vagy ritkán betartott) előírás az egészségügyi ellátás során, még kevésbé az úgynevezett egészséges populációban. Természetesen lehetetlen a társadalom minden egyedét megmérni, így a különböző, populációs szintű vizsgálatoknak megfelelő reprezentativitást kell biztosítaniuk, aminek elérésére különféle mintavételi módszereket alkalmaznak. Az első és mindeddig legnagyobb szabású hazai felmérést, az Elsö Magyar Reprezentatív Táplálkozási Vizsgálatot 1985-1988 között végezték. Ezt az Országos Élelmezési és Táplálkozástu- dományi Intézet (OÉTI) koordinálta, a végrehajtásba bevonva a korabeli „népegészségügyi szakigazgatási szervek" (Köjál) munkatársait is. Ez egy professzionálisan tervezett, szervezett és lebonyolított vizsgálat volt, valamennyi megyére kiterjedően, elsősorban a munkahelyeken megkeresve a vizsgálatok alanyait, igyekezvén elérni a minél nagyobb fokú reprezentativitást. A vizsgálatban az antropometriai méréseken kívül a táplálkozási szokásokat, megbetegedéseket és az életkörülményeket is regisztrálták, megkeresve, megmérve és kikérdezve 16641 személyt (7042 férfit és 9599 nőt). Az eredményeket a korabeli informatikai lehetőségek alapján az akkor rendelkezésre álló módszerekkel dolgozták fel. Az összes életkori csoport átlagában a túlsúly (BMI>25 kg/ $\mathrm{m}^{2}$ ) előfordulása a férfiaknál $41,6 \%$, nőknél $32,1 \%$ volt, míg elbizást $\left(B M I>30 \mathrm{~kg} / \mathrm{m}^{2}\right)$ regisztráltak a férfiak 11,6\%-ánál és a nők 18,1\%-ánál [4].

Hasonló módszerrel, de lényegesen kisebb elemszámú vizsgálatot is végzett az OÉTI közel egy évtizeddel később, amelynek során 2568 személyt mértek meg különböző életkori csoportokban. A megvizsgált 1164 férfi között a túlsúly 41,9\% volt, míg az elhizás 21,0\%. A túlsúlyosság 27,9\%-ban, az elhíá́s 21,1\%-ban volt jelen a vizsgálatban részt vevő 1404 nő között [5].

Újabb 10 évvel később egy nagyszabású alapellátási morbiditási vizsgálat során a 40-70 év közötti életkori tartományban 45\%-os túlsúly- és 32\%-os elhízásprevalenciát írtak le, közöttük 3\% morbid elhízott volt [6].

Egy 2009-ben végzett, országos reprezentativitásra törekvő táplálkozási vizsgálatban 1165 személyt tudtak megmérni a szakemberek. A BMI átlagértékei hasonló életkori csoportokban meghatározva a következők voltak: férfiaknál 18-34 év $=25,0 \mathrm{~kg} / \mathrm{m}^{2}, 35-64$ év $=28,4$ $\mathrm{kg} / \mathrm{m}^{2}$ és 65 év felett $=28,7 \mathrm{~kg} / \mathrm{m}^{2}$. Ugyanezekben az életkori kategóriákban nőknél ezek az értékek 23,6 kg/ $\mathrm{m}^{2}, 28,1 \mathrm{~kg} / \mathrm{m}^{2}$ és $29,8 \mathrm{~kg} / \mathrm{m}^{2}$ voltak. Elhízást diagnosztizáltak a férfiak 26,2\%-ánál, a nők 30,4\%-ánál, míg a morbid elhízás aránya 3,1 és $2,6 \%$ volt. A hasi elhízás gyakrabban fordult elő nőknél, mint férfiaknál (51,0\% vs. $33,2 \%)$ és prevalenciája mindkét nemben az életkorral párhuzamosan nött [7]. 
Az európai vizsgálat részeként 2009-ben országszerte 27746 résztvevő saját mérésü adatait regisztrálták az Országos Lakossági Egészség Felmérés (OLEF) során [8]. E szerint 65 év felett a férfiak közel fele, a nók közel 40\%-a elhízott, a legfiatalabb (18-34 év) korcsoportban minden hatodik. A 35-64 év közötti korosztályban az elhízottak aránya egyharmad körüli volt a bemondott adatok alapján.

Egy szakmailag homogénebb populációt vizsgáltak a rendőri állomány 2002-es felmérése során. A bevont (20-55 év közötti) 18763 rendőr és 2037 rendőrnő körében az elhízást 19,1\%-ban, a túlsúlyt 43,8\%-ban állapították meg. Férfiaknál a 94-102 cm közötti derékkörfogat előfordulása $21,9 \%$, míg a $102 \mathrm{~cm}$ felettiek aránya $22,6 \%$ volt. Az elhízott rendőrök aránya az életkorral nőtt, míg 20-25 év között 11,8\%, a 40-45 év közöttieknél már 29,3\% volt. Földrajzi különbségek is mutatkoztak; a fóvárosiak között 15,3\%, míg a vidéki rendőrök körében 19,4\% volt az elhízottak aránya [9].

A WHO honlapján található, nem megjelölt forrású adatok szerint Magyarországon a férfiak 26,2\%-a, a nők 22,9\%-a elhízott. Túlsúlyosnak tartják a férfiak 65,8 és a nők 49,4\%-át [10, 11]. Korosztályos adatokat nem találtunk.

Mivel az utóbbi negyed évszázadban hazánkban valóban nagyszabású, ugyanakkor reprezentatív és szakszemélyzet általi mérési adatokon alapuló vizsgálat nem történt, ezért közösségi színtereken és alapellátási körülmények között történő vizsgálatokat terveztünk meg és bonyolítottunk le az utóbbi években, két lépcsőben.

\section{Módszer}

Az első fázis vizsgálatai 2012 szeptembere és 2013 áprilisa, a második 2014 februárja és 2015 áprilisa között történtek. A bemutatott adatok legnagyobb része az első ütemben, a háziorvosi rendelőkben bármely ok miatt megforduló személyekkel és egyéb közösségi színtereken végzett tevékenységek (foglalkozás-egészségügyi vizsgálat, lakossági-munkahelyi egészségfejlesztés) során történt találkozások alkalmával keletkezett [12]. A pontosabb földrajzi reprezentativitás elérésére végeztük el a vizsgálat második szakaszát, elsősorban a fővárosra fókuszálva, a korábbi adatokat kiegészítve a frissebbekkel.

A felmérésbe csak 18 évnél idősebb személyeket vontunk be. Az első 200 személy vagy páciens bevonását kértük a vizsgálóktól. Kizárási feltétel volt az intézeti elhelyezés, vagy bármely olyan megbetegedés jelenléte, akár gyanúja, amely a tápláltsági állapotot befolyásolhatja: daganatos, emésztőszervi, anyagcsere-, endokrin megbetegedések, krónikus obstruktív tüdőbetegség, cystás fibrosis, terhesség, szoptatás, veseelégtelenség, extrém testalkat (morbid elhízás, cachexia), bármely más,

1. táblázat | BMI. A vizsgáltak megoszlása a különböző BMI-kategóriák között, életkori szakaszok, illetve évtizedek (dekádok) szerinti beosztásban (\%). A jelenlegi felmérés adatainak összehasonlítása a korábbi nagyszabású hazai vizsgálattal [4]

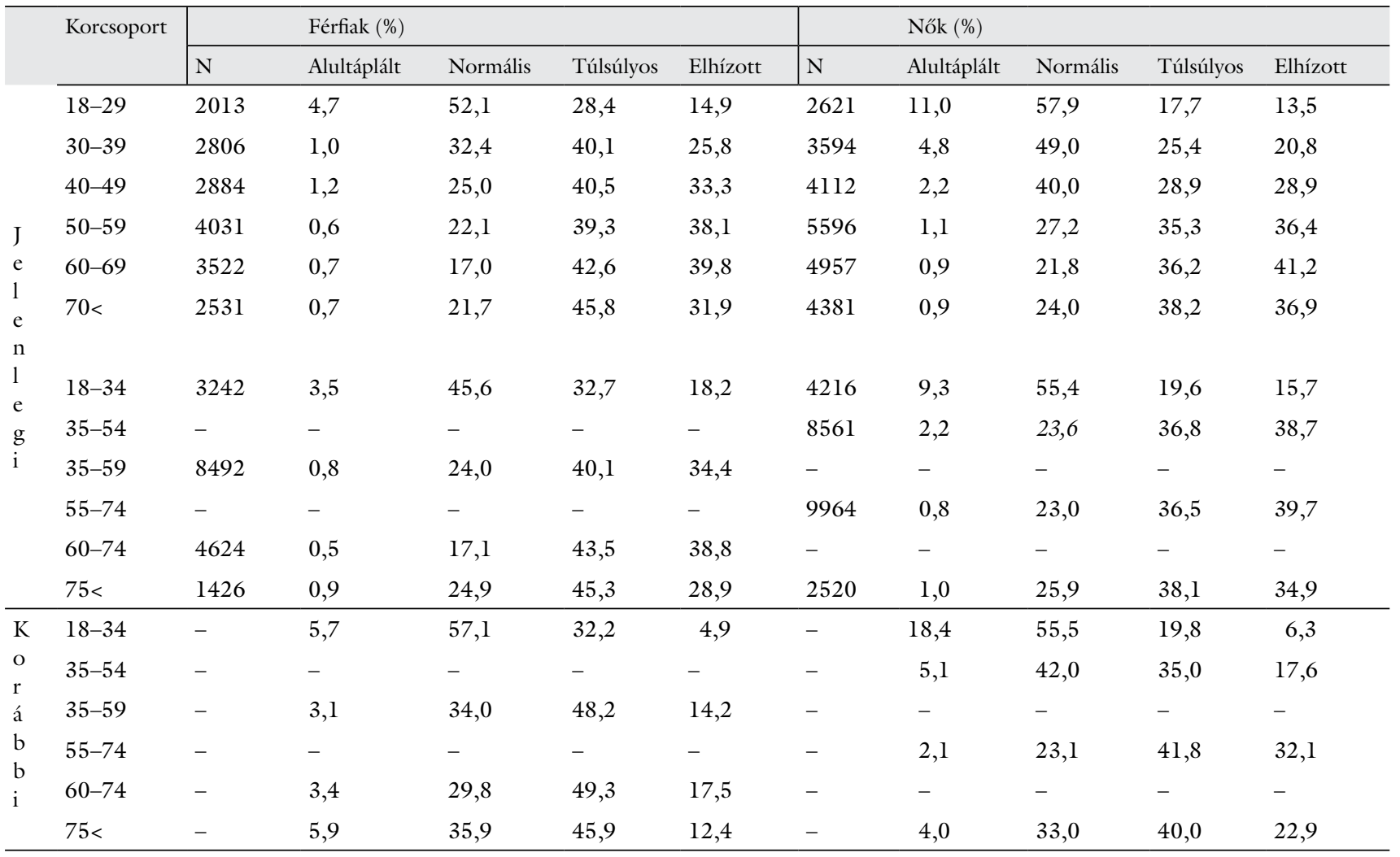


táplálkozáshoz köthető betegség, korábbi visszatérő „fogyókúrák”.

A részvétel kizárólag önkéntesen történt, a vizsgálatból való kizárás a vizsgáló orvos kompetenciája volt. A vizsgálatra etikai engedélyt kaptunk (ETT-TUKEB 20928-I).

Az ország minden részéből megkerestünk háziorvosokat, jellemzően az egyetemek oktató családorvosai köréből, olyanokat preferálva, akik foglalkozás-orvosi (üzemorvosi) ellátást is nyújtanak munkahelyi színtereken. A vizsgálat írásos protokollját megküldtük számukra. A minél nagyobb részvétel elérése céljából fontos szempont volt a vizsgálat egyszerüsége és csupán kevés adat regisztrálása. Az adatgyújtő orvosok egy része kisebb kompenzálásban (szakkönyv, ingyenes tanfolyami részvétel) részesült.

A regisztrálás papíralapon vagy elektronikusan kitöltött és így megküldött táblázatban történt, amelyben a következő adatokat kértük, kizárólag szakember (orvos vagy nővér) általi mérés alapján:

- Testmagasság (cm): Mezítláb, hitelesített stadiométerrel mérve, a fejet a Frankfort-vonalban tartva (a szem alsó vonalát és a külső hallójárattal összekötő képzeletbeli egyenes, a vízszintes síkban).

- Testtömeg (kg): Kalibrált mérlegen, alsóruházatban vagy nagyon könnyü öltözékben, éhgyomorral, üres hólyaggal, lehetőleg székelés után.

- Derékkörfogat $(\mathrm{cm})$ : Hitelesített mérőszalaggal, vízszintes síkban, az alsó bordaív és a felső csípőlapát között félúton mérve.

A fenti adatokat egész számban, a kerekítés szabályai szerint kértük rögzíteni.

A már korábban diagnosztizált metabolikus megbetegedések közül a hypertonia és/vagy a diabetes jelenlétét is bejelölték az orvosok.

Iskolázottság. A vizsgált személyek legmagasabb iskolai végzettsége és kódjaik:

0 - amennyiben a 8 általánost nem fejezte be,

1 - elvégzett 8 általános (a legidősebbeknél 4 polgári iskola),

2 - befejezett középiskolai tanulmányok vagy szakmunkásiskola,

3 - felsőfokú végzettség (egyetem vagy föiskola).

A testtömegindex (BMI) számítása után az értékeket a nemzetközileg elfogadott kategóriabeosztás alapján adtuk meg [1]: alultáplált $<18,5$, normális súlyú $=18,5-$ 24,9 , túlsúlyos $=25-29,9$, elbizott $>30 \mathrm{~kg} / \mathrm{m}^{2}$ értékeknél.

A derékkörfogat kategóriáit a cardiovascularis megbetegedés veszélyeztetettsége szempontjából értékeltük, normálértéknek tekintve férfiaknál a $94 \mathrm{~cm}$, nőknél a 80 cm alatti, „veszélyeztetett"-nek a 94-102 cm, illetve a 80-88 cm közötti értékeket, míg e fölött hasi elhizást jelöltünk $[1,13]$.

Az adatok elemzése során deskriptív statisztikai módszereket alkalmaztunk elsősorban. Az egyes táblázatokban alkalmazott logisztikus regressziós modellel talált összefüggéseket esélyhányadosok $(\mathrm{EH})$ és a hozzájuk tartozó 95\%-os megbízhatósági tartományok (95\% MT) segítségével mutatjuk be. A statisztikai elemzés a STATA program 9.2. verziójával történt.

\section{Eredmények}

A vizsgált személyek közül 43287 fó (17 901 férfi és 25386 nő) adatai voltak alkalmasak teljes körű elemzésre.

A részt vevő háziorvosi praxisok Magyarország minden régióját lefedték, összesen 244 körzetet, ami a felnőtteket kezelő hazai családorvosok 4,5\%-ának bevonását jelentette. Ezek közül 38 Budapesten, 99 a városokban, 107 (nagy)községekben múködik.

Az 1. táblázat a legfontosabb BMI-prevalencia-adatokat szemlélteti, összehasonlítva az 1988-as eredményekkel [4]. Az általunk mért adatokat többnyire életkori dekádonként mutatjuk be, de az összehasonlíthatóság kedvéért esetenként a hivatkozott vizsgálatokban alkalmazott hosszabb idejü életkori csoportokban is megadjuk. Bármelyiket is nézzük, jól látható a magasabb BMIkategóriák felé való eltolódás, fóleg a BMI emelkedésével.

A 2. táblázatban a kétféle életkori beosztásban is csoportosított testtömegindex-adatainkat hasonlítjuk össze

2. táblázat $\mid$ BMI-átlag. Átlagok a különböző életkori kategóriákban. Összehasonlítás a jelenlegi és a korábbi adatok között [4]

\begin{tabular}{|c|c|c|c|}
\hline \multicolumn{2}{|c|}{ Korcsoport } & $\begin{array}{l}\text { Férfiak } \\
\text { BMI }\left(\mathrm{kg} / \mathrm{m}^{2}\right) \\
\text { átlag }( \pm \mathrm{SD})\end{array}$ & $\begin{array}{l}\text { Nők } \\
\text { BMI }\left(\mathrm{kg} / \mathrm{m}^{2}\right) \\
\text { átlag }( \pm \mathrm{SD})\end{array}$ \\
\hline $\mathrm{J}$ & $18-29$ & $25,0( \pm 4,9)$ & $23,7( \pm 5,4)$ \\
\hline $\begin{array}{l}\mathrm{e} \\
1\end{array}$ & $30-39$ & $27,4( \pm 4,9)$ & $25,7( \pm 5,8)$ \\
\hline e & $40-49$ & $28,4( \pm 5,4)$ & $27,2( \pm 5,9)$ \\
\hline $\begin{array}{l}n \\
1\end{array}$ & $50-59$ & $29,0( \pm 5,4)$ & $28,6( \pm 5,7)$ \\
\hline $\mathrm{e}$ & $60-69$ & $29,3( \pm 5,0)$ & $29,3( \pm 5,5)$ \\
\hline \multirow[t]{6}{*}{$\begin{array}{l}\mathrm{g} \\
\mathrm{i}\end{array}$} & $70<$ & $28,3( \pm 4,5)$ & $28,6( \pm 5,2)$ \\
\hline & $18-34$ & $25,8( \pm 5,0)$ & $24,3( \pm 5,6)$ \\
\hline & $35-59$ & $28,6( \pm 5,3)$ & - \\
\hline & $35-54$ & - & $27,3( \pm 5,9)$ \\
\hline & $55<$ & - & $28,9( \pm 5,4)$ \\
\hline & $60<$ & $28,9( \pm 4,8)$ & - \\
\hline \multicolumn{4}{|c|}{$\mathrm{K}$} \\
\hline $\begin{array}{l}\mathrm{O} \\
\mathrm{r}\end{array}$ & $18-34$ & 24,2 & 23,3 \\
\hline á & $35-59$ & 26,3 & - \\
\hline $\begin{array}{l}b \\
b\end{array}$ & $35-54$ & - & 26,0 \\
\hline \multirow[t]{3}{*}{$\mathrm{i}$} & $55-74$ & - & 28,1 \\
\hline & $60-74$ & 26,7 & - \\
\hline & $75<$ & 25,8 & 27,0 \\
\hline
\end{tabular}


a negyedszázaddal ezelőtti vizsgálat [4] BMI-átlagaival, amelyek azóta láthatóan nagyobbak lettek már a fiataloknál is, a 35. életévtől kezdve $2 \mathrm{~kg} / \mathrm{m}^{2}$ körüli BMI-növekedést jelentve.

A 3. táblázat az iskolai végzettség megoszlását mutatja a testtömegindex és életkori csoportok szerint, míg a 4. táblázat a lakóhely/település típusának megoszlását.

3. táblázat $\mid \mathrm{Az}$ iskolai végzettség megoszlása nemenként (\%), a BMI- és életkori csoportokban

\begin{tabular}{llcccc}
\hline Csoportok & \multicolumn{3}{l}{ Iskolai végzettség } \\
\cline { 3 - 6 } & & $\begin{array}{l}<\text { általános } \\
(\%)\end{array}$ & $\begin{array}{l}\text { Általános } \\
(\%)\end{array}$ & $\begin{array}{l}\text { Középfokú } \\
(\%)\end{array}$ & $\begin{array}{l}\text { Felsőfokú } \\
(\%)\end{array}$ \\
\hline Férfiak & Alultáplált & 1,9 & 2,0 & 1,2 & 0,8 \\
BMI & Normális & 30,7 & 28,0 & 25,7 & 28,1 \\
& Túlsúlyos & 39,2 & 35,6 & 39,9 & 43,9 \\
& Elhízott & 28,2 & 34,4 & 33,1 & 27,2 \\
\hline Életkori & $18-34$ & 9,4 & 12,9 & 21,5 & 22,2 \\
& $35-59$ & 40,0 & 46,3 & 50,3 & 46,1 \\
& $60<$ & 50,6 & 40,8 & 28,3 & 31,7 \\
\hline Nók & Alultáplált & 3,2 & 2,8 & 3,0 & 2,5 \\
BMI & Normális & 26,5 & 26,6 & 36,6 & 46,6 \\
& Túlsúlyos & 29,6 & 32,7 & 32,1 & 28,6 \\
& Elhízott & 40,8 & 38,0 & 28,3 & 22,4 \\
\hline Életkori & $18-34$ & 9,6 & 10,6 & 19,8 & 26,6 \\
& $35-59$ & 33,6 & 38,5 & 53,3 & 52,7 \\
& $60<$ & 56,7 & 50,9 & 26,9 & 20,7 \\
\hline
\end{tabular}

4. táblázat $\mid$ Lakóhely, településtípus szerinti megoszlás nemenként (\%), a BMI- és az életkori csoportokban

\begin{tabular}{|c|c|c|c|c|}
\hline \multicolumn{2}{|c|}{ Csoportok } & Budapest (\%) & Város (\%) & Község (\%) \\
\hline Férfiak & Alultáplált & 1,7 & 1,3 & 1,2 \\
\hline \multirow{3}{*}{ BMI } & Normális & 27,1 & 26,3 & 27,1 \\
\hline & Túlsúlyos & 39,1 & 41,4 & 37,9 \\
\hline & Elhízott & 32,1 & 31,0 & 33,9 \\
\hline \multirow[t]{3}{*}{ Életkori } & $18-34$ & 24,8 & 18,2 & 16,2 \\
\hline & $35-59$ & 46,3 & 47,2 & 49,0 \\
\hline & $60<$ & 28,9 & 34,5 & 34,8 \\
\hline Nők & Alultáplált & 2,2 & 2,8 & 2,9 \\
\hline \multirow{3}{*}{ BMI } & Normális & 33,1 & 37,2 & 29,9 \\
\hline & Túlsúlyos & 34,9 & 31,5 & 31,1 \\
\hline & Elhízott & 29,8 & 28,5 & 36,1 \\
\hline \multirow[t]{3}{*}{ Életkori } & $18-34$ & 22,5 & 16,4 & 15,8 \\
\hline & $35-59$ & 43,6 & 46,5 & 46,8 \\
\hline & $60<$ & 33,9 & 37,2 & 37,4 \\
\hline
\end{tabular}

5. táblázat

Derékkörfogat. A normális és kóros (fokozott cardiovascularis kockázatot, illetve hasi elhízást jelentő) derékkörfogat-kategóriák megoszlása nemenként, az életkori dekádokban, településtípusok és iskolázottság szerint

\begin{tabular}{|c|c|c|c|c|}
\hline Férfiak & & $\begin{array}{l}<94 \mathrm{~cm} \\
(\%)\end{array}$ & $\begin{array}{l}94-102 \mathrm{~cm} \\
(\%)\end{array}$ & $\begin{array}{l}102 \mathrm{~cm}< \\
(\%)\end{array}$ \\
\hline \multirow[t]{6}{*}{ Korcsoport } & $18-29$ & 72,1 & 14,4 & 13,5 \\
\hline & $30-39$ & 51,4 & 23,0 & 25,5 \\
\hline & $40-49$ & 39,4 & 24,5 & 36,2 \\
\hline & $50-59$ & 30,9 & 25,8 & 43,3 \\
\hline & $60-69$ & 26,0 & 25,3 & 48,7 \\
\hline & $70<$ & 29,1 & 28,1 & 42,9 \\
\hline \multirow[t]{3}{*}{ Településtípus } & Budapest & 43,5 & 23,0 & 33,2 \\
\hline & Város & 38,7 & 24,3 & 37,1 \\
\hline & Község & 38,6 & 23,8 & 37,6 \\
\hline \multirow[t]{4}{*}{ Iskolázottság } & $<8$ általános & 39,9 & 23,0 & 37,0 \\
\hline & Általános & 38,4 & 23,0 & 38,6 \\
\hline & Középfokú & 38,4 & 23,4 & 38,1 \\
\hline & Felsőfokú & 41,2 & 25,7 & 33,2 \\
\hline Nők & & $\begin{array}{l}<80 \mathrm{~cm} \\
(\%)\end{array}$ & $\begin{array}{l}80-88 \mathrm{~cm} \\
(\%)\end{array}$ & $\begin{array}{l}88 \mathrm{~cm}< \\
(\%)\end{array}$ \\
\hline \multirow[t]{6}{*}{ Korcsoport } & $18-29$ & 56,9 & 18,4 & 24,7 \\
\hline & $30-39$ & 40,7 & 20,4 & 38,9 \\
\hline & $40-49$ & 28,7 & 19,6 & 51,8 \\
\hline & $50-59$ & 16,4 & 16,7 & 67,0 \\
\hline & $60-69$ & 10,9 & 14,4 & 74,7 \\
\hline & $70<$ & 13,1 & 13,3 & 73,6 \\
\hline \multirow[t]{3}{*}{ Településtípus } & Budapest & 47,8 & 17,0 & 35,2 \\
\hline & Város & 24,3 & 17,5 & 58,2 \\
\hline & Község & 19,6 & 15,8 & 64,7 \\
\hline \multirow[t]{4}{*}{ Iskolázottság } & $<8$ általános & 17,2 & 12,6 & 70,2 \\
\hline & Általános & 16,9 & 14,2 & 68,9 \\
\hline & Középfokú & 27,2 & 18,3 & 54,6 \\
\hline & Felsőfokú & 38,3 & 19,4 & 42,3 \\
\hline
\end{tabular}

Az elhízottak aránya férfiaknál a csak általános iskolát végzetteknél, nóknél az ennél is kevésbé iskolázottaknál volt a legmagasabb. Férfiaknál túlsúly a legnagyobb arányban a felsőfokú végzettségúek között volt, ugyanakkor mindkét nemben náluk volt a legalacsonyabb az elhízottak aránya. Az iskolai végzettség nagyjából a társadalmi trendeket mutatta, a középső életkori kategóriában volt magasabb. Az elhízás legnagyobb arányban a községekben volt kimutatható mindkét nemben, míg férfiaknál a túlsúlyosak domináltak mindhárom lakóhely szerinti kategóriában. Nőknél a városlakók között határozták meg a legtöbb normális BMI-t és itt találták a legkevesebb elhízottat. 
A kóros derékkörfogati kategóriákban lévők aránya az életkori dekádokon át fokozatosan növekszik, mindkét nemben a 70. életévig. Az 5. táblázat szerint a hasi típusú elhízás a falvak lakóinál a legnagyobb arányú, különösen a nőknél. A budapesti lakosok legnagyobb része a normális csoportba tartozik. Férfiaknál a felsőfokú végzettségű kategóriában a legkisebb a hasi elhízás aránya és legnagyobb a normális haskörfogaté. Nők esetében az általános iskolát vagy annál kevesebbet végzettek kétharmada a hasi elhízott kategóriába tartozik, ami legkevésbé a diplomás asszonyokra jellemző, akik a normális kategóriában a legmagasabb arányt képviselik.

Az elhízottak kategóriájában (a BMI és a hasi elhízás alapján értékelve egyaránt) inverz összefüggés volt az alapfokú képzettséghez viszonyított, az adott BMI-kate- góriába kerülés esélye $(\mathrm{EH})$ és az iskolázottság szintje között. Mindkét nemben ezek az összefüggések statisztikailag többnyire szignifikánsnak bizonyultak, összehasonlítva az alapfokú és az ennél magasabb iskolázottsági szinteket a 6. táblázat adatai alapján.

A felmérés során regisztrált metabolikus betegségek (hypertonia, diabetes) prevalenciája jellemzően a vizsgált személyek 50. életévétől nő meg. E fölött már több a (valamelyik vagy mindkét kórképben szenvedő) beteg a felmért populációban, mint a nem beteg. A vizsgált megbetegedések kialakulására kisebb esélye van a fóvárosban, mint a városokban vagy a falvakban lakóknak. A magasabb iskolai végzettség mindkét nemben kisebb megbetegedési esélyeket jelentett, amelyek számszerúen a 7 . táblázatban láthatók.

6. táblázat $\mid$ Az iskolázottság, BMI és derékkörfogat kategóriái. A vizsgáltak megoszlása (\%) - Esélyhányadosok (EH) és megbízhatósági tartományok (95\% MT) az alapfokú (általános) iskolai végzettséghez viszonyítva

(Szignifikáns eltérések kiemelve és *)

\begin{tabular}{|c|c|c|c|c|c|c|c|}
\hline \multirow[t]{2}{*}{ Képzettség } & \multicolumn{4}{|c|}{ BMI-kategória } & \multicolumn{3}{|c|}{ Derékkörfoga-kategória } \\
\hline & Alultáplált & Normális & Túlsúlyos & Elhízott & Normális & $\begin{array}{l}\text { Fokozott } \\
\text { kockázat }\end{array}$ & Hasi elhízás \\
\hline & \multicolumn{7}{|l|}{ Férfiak (\%) } \\
\hline $\begin{array}{l}\text { Alapfokú } \\
\text { (<8 általános) }\end{array}$ & 1,92 & 30,7 & 39,2 & 28,2 & 39,9 & 23,0 & 37,0 \\
\hline $\begin{array}{l}\mathrm{EH} \\
(95 \% \mathrm{MT})\end{array}$ & $\begin{array}{l}0,974 \\
(0,50-1,89)\end{array}$ & $\begin{array}{l}1,138 \\
(0,93-1,39)\end{array}$ & $\begin{array}{l}1,163 \\
(0,97-1,40)\end{array}$ & $\begin{array}{l}0,749 * \\
(0,61-0,92)\end{array}$ & $\begin{array}{l}1,064 \\
(0,88-1,28)\end{array}$ & $\begin{array}{l}1,003 \\
(0,80-1,24)\end{array}$ & $\begin{array}{l}0,936 \\
(0,78-1,13)\end{array}$ \\
\hline Általános & 2,0 & 28,0 & 35,6 & 34,4 & 38,4 & 23,0 & 38,6 \\
\hline $\begin{array}{l}\mathrm{EH} \\
(95 \% \mathrm{MT})\end{array}$ & 1,00 & 1,00 & 1,00 & 1,00 & 1,00 & 1,00 & 1,00 \\
\hline Középfokú & 1,2 & 25,7 & 39,9 & 33,1 & 38,4 & 23,4 & 38,1 \\
\hline $\begin{array}{l}\mathrm{EH} \\
(95 \% \mathrm{MT})\end{array}$ & $\begin{array}{l}0,625^{*} \\
(0,47-0,84)\end{array}$ & $\begin{array}{l}0,888^{*} \\
(0,82-0,97)\end{array}$ & $\begin{array}{l}1,202 * \\
(1,11-1,30)\end{array}$ & $\begin{array}{l}0,944 \\
(0,87-1,02)\end{array}$ & $\begin{array}{l}1,000 \\
(0,93-1,08)\end{array}$ & $\begin{array}{l}1,025 \\
(0,94-1,12)\end{array}$ & $\begin{array}{l}0,980 \\
(0,90-1,06)\end{array}$ \\
\hline Felsőfokú & 0,8 & 28,1 & 43,9 & 27,2 & 41,2 & 25,7 & 33,2 \\
\hline \multirow[t]{2}{*}{$\begin{array}{l}\mathrm{EH} \\
(95 \% \mathrm{MT})\end{array}$} & $\begin{array}{l}0,415^{*} \\
(0,26-0,67)\end{array}$ & $\begin{array}{l}1,003 \\
(0,90-1,12)\end{array}$ & $\begin{array}{l}1,414^{*} \\
(1,28-1,56)\end{array}$ & $\begin{array}{l}0,712^{*} \\
(0,64-0,79)\end{array}$ & $\begin{array}{l}1,120 * \\
(1,01-1,23)\end{array}$ & $\begin{array}{l}1,158^{*} \\
(1,03-1,29)\end{array}$ & $\begin{array}{l}0,788^{*} \\
(0,71-0,87)\end{array}$ \\
\hline & \multicolumn{7}{|l|}{ Nők (\%) } \\
\hline $\begin{array}{l}\text { Alapfokú } \\
\text { (<8 általános) }\end{array}$ & 3,2 & 26,5 & 29,6 & 40,8 & 17,2 & 12,6 & 70,2 \\
\hline $\begin{array}{l}\text { EH } \\
(95 \% \mathrm{MT})\end{array}$ & $\begin{array}{l}1,142 \\
(0,80-1,62)\end{array}$ & $\begin{array}{l}0,996 \\
(0,87-1,14)\end{array}$ & $\begin{array}{l}0,866^{*} \\
(0,76-0,99)\end{array}$ & $\begin{array}{l}1,122 \\
(0,99-1,27)\end{array}$ & $\begin{array}{l}1,024 \\
(0,87-1,20)\end{array}$ & $\begin{array}{l}0,871 \\
(0,73-1,04)\end{array}$ & $\begin{array}{l}1,061 \\
(0,92-1,21)\end{array}$ \\
\hline Általános & 2,8 & 26,6 & 32,7 & 38,0 & 16,9 & 14,2 & 68,9 \\
\hline $\begin{array}{l}\mathrm{EH} \\
(95 \% \mathrm{MT})\end{array}$ & 1,00 & 1,00 & 1,00 & 1,00 & 1,00 & 1,00 & 1,00 \\
\hline Középfokú & 3,0 & 36,6 & 32,1 & 28,3 & 27,2 & 18,3 & 54,6 \\
\hline $\begin{array}{l}\mathrm{EH} \\
(95 \% \mathrm{MT})\end{array}$ & $\begin{array}{l}1,091 \\
(0,91-1,31)\end{array}$ & $\begin{array}{l}1,594^{*} \\
(1,49-1,70)\end{array}$ & $\begin{array}{l}0,973 \\
(0,91-1,03)\end{array}$ & $\begin{array}{l}0,644^{*} \\
(0,60-0,69)\end{array}$ & $\begin{array}{l}1,838^{*} \\
(1,70-1,98)\end{array}$ & $\begin{array}{l}1,346^{*} \\
(1,24-1,46)\end{array}$ & $\begin{array}{l}0,542 * \\
(0,50-0,57)\end{array}$ \\
\hline Felsőfokú & 2,5 & 46,6 & 28,6 & 22,4 & 38,3 & 19,4 & 42,3 \\
\hline $\begin{array}{l}\mathrm{EH} \\
(95 \% \mathrm{MT})\end{array}$ & $\begin{array}{l}0,892 \\
(0,69-1,15)\end{array}$ & $\begin{array}{l}2,410^{*} \\
(2,22-2,62)\end{array}$ & $\begin{array}{l}0,824^{*} \\
(0,75-0,90)\end{array}$ & $\begin{array}{l}0,470 * \\
(0,42-0,52)\end{array}$ & $\begin{array}{l}3,063^{*} \\
(2,79-3,35)\end{array}$ & $\begin{array}{l}1,449 * \\
(1,30-1,61)\end{array}$ & $\begin{array}{l}0,330 * \\
(0,30-0,36)\end{array}$ \\
\hline
\end{tabular}


7. táblázat $\mid$ Megbetegedések. Esélyhányadosok (EH), standard hiba (SH), a szignifikancia szintje és a 95\%-os megbízhatósági tartományok (MT) a metabolikus megbetegedések (hypertonia és/vagy diabetes) jelenlétére, a lakóhelyre, iskolázottságra és a BMI-kategóriákra vonatkozóan

\begin{tabular}{|c|c|c|c|c|c|c|c|c|c|c|}
\hline \multirow[t]{2}{*}{ Kategóriák } & \multicolumn{5}{|l|}{ Férfiak } & \multicolumn{5}{|l|}{ Nők } \\
\hline & $\mathrm{EH}$ & SH & $\mathrm{P}>\mathrm{z}$ & $95 \% \mathrm{M}^{\prime}$ & & $\mathrm{EH}$ & SH & $\mathrm{P}>\mathrm{z}$ & $95 \% \mathrm{M}^{\prime}$ & \\
\hline Ref. Budapest & 1,00 & & & & & 1,00 & & & & \\
\hline Város & 1,401 & 0,080 & $<0,001$ & 1,252 & 1,567 & 1,559 & 0,081 & $<0,001$ & 1,409 & 1,726 \\
\hline Falu & 1,351 & 0,083 & $<0,001$ & 1,198 & 1,523 & 1,317 & 0,072 & $<0,001$ & 1,184 & 1,466 \\
\hline Ref. Alapfokú & 1,00 & & & & & 1,00 & & & & \\
\hline Alacsonyabb & 0,801 & 0,072 & 0,013 & 0,672 & 0,953 & 0,986 & 0,071 & 0,846 & 0,857 & 1,135 \\
\hline Középfokú & 0,656 & 0,027 & $<0,001$ & 0,605 & 0,711 & 0,462 & 0,016 & $<0,001$ & 0,431 & 0,495 \\
\hline Felsőfokú & 0,602 & 0,033 & $<0,001$ & 0,542 & 0,669 & 0,283 & 0,013 & $<0,001$ & 0,258 & 0,310 \\
\hline Ref. Normális & 1,00 & & & & & 1,00 & & & & \\
\hline Alultáplált & 4,516 & 0,209 & $<0,001$ & 4,125 & 4,944 & 4,677 & 0,179 & $<0,001$ & 4,339 & 5,040 \\
\hline Túlsúlyos & 2,294 & 0,097 & $<0,001$ & 2,112 & 2,493 & 2,529 & 0,090 & $<0,001$ & 2,358 & 2,713 \\
\hline Elhízott & 0,695 & 0,108 & 0,019 & 0,512 & 0,942 & 0,359 & 0,039 & $<0,001$ & 0,291 & 0,444 \\
\hline
\end{tabular}

\section{Megbeszélés}

Összehasonlítva a negyedszázaddal ezelőtt mért adatokkal, a BMI átlagértékei minden életkori kategóriában jelentősen emelkedtek. A korábbi nagy hazai vizsgálatban más életkori beosztást alkalmaztak a nóknél, az akkori jogszabályok idején alacsonyabb nyugdíjkorhatáruk miatt [4]. A populáció megoszlása is változott, a túlsúlyosak nagyobb arányban váltak elhízottakká, ami 2-4-szeres emelkedést jelentett több életkori kategóriában is. Ez az eltolódás különösen a férfiaknál volt látványos, BMIjük már a középső életkori dekádokban nagyobb volt, míg korábban a nóknél volt megfigyelhetô ez a trend [4]. A hasi típusú elhízás nőknél jelentősebb, megegyezően másik, friss hazai vizsgálattal [7].

Lényeges eltérések voltak az iskolázottsági és testtömegindex-kategóriák vonatkozásában. A legmagasabb iskolai végzettségúek között volt a legalacsonyabb az elhízottak, ugyanakkor a legmagasabb a túlsúlyosak aránya.

A regisztrált metabolikus megbetegedések aránya szoros korrelációban volt a BMI-csoportokkal, a magasabbaknál nagyobb arányban, inverz korrelációt mutatva az urbanizáció szintjével.

Összehasonlítva a vizsgálataink két fázisában rögzített adatokat, azok lényeges eltérést nem mutattak. A vizsgált fóvárosiak átlagéletkora 52,8 év volt az első mérések idején, a későbbiekben vizsgáltaké 49,1 év. A bevont elhízottak aránya $28,9 \%$, majd $30,8 \%$ volt, a túlsúlyosak 37,1\%-os, késóbb 36,5\%-os arányt képviseltek.

Az Elsö Magyar Reprezentatín Táplálkozási Vizsgálat idején hazánk lakossága még 10,6 millió fó volt. A vizsgálatba bevontak aránya a korabeli teljes lakosságszám $0,16 \%$-át jelentette. A napjainkra sajnálatosan 10 millió alá csökkent lakosságszámból vizsgálatunkba a 18 évesnél idősebb populáció $0,55 \%$-át sikerült bevonnunk. Ez hasonló részarányt jelent, mintha például az Egyesült Királyságban 300 ezer, az Amerikai Egyesült Államokban 1,5 millió lakost mértek volna meg, de ezekből az országokból még ezt megközelítő esetszámú vizsgálatokról sem találtunk adatokat. A korábbi nagy hazai vizsgálatban a derékkörfogatot még nem mérték meg, bár más antropometriai indexek (ponderális index, bőrredő stb.) meghatározásra kerültek. Szintén nem elemezték az iskolázottság, a morbiditás és az antropometriai paraméterek összefüggéseit. A nőknél az eltérő életkori határok és korábban az alultápláltságnál meghúzott $20 \mathrm{~kg} / \mathrm{m}^{2}$-es küszöbérték is eltérő volt.

A reprezentativitásnak meg kell felelnie a földrajzi (lakóhelyi) megoszlás feltételeinek, az életkori, iskolázottsági szempontoknak, bár a nagyszabású vizsgálatok megtervezése, végrehajtása néha kisebb-nagyobb kompromisszumokat is igényel. A legtöbb idézett hazai vizsgálatban a reprezentativitás mint elérendő cél ugyan szerepelt, megvalósulásáról viszont többnyire hiányzott az információ.

Az iskolázottság szintjeinél csaknem teljes volt az átfedés: az alacsony ( $<8$ általános iskola) képzettségúeknél $5 \%$ volt a népszámláláskor, nálunk $4,7 \%$, alapfokú végzettségúeknél $27 \%$ vs. $32,5 \%$, a középiskolát befejezetteknél $51 \%$ vs. $46 \%$, míg a felsőfokú végzettségúeknél $14 \%$ vs. $16,8 \%$.

Lakóhely szerint elfogadható az eltérés. Bár 34 éves korig az arányok ugyanazok voltak, de a többi korosztályban a fővárosi lakosság kissé alulreprezentált volt a vizsgálatban $(17,5 \%$ a népszámláláskor, nálunk 9,6\%). A többi városlakónál $(51,8 \%$ vs. 53,9$)$, a községekben élőknél $(30,7 \%$ vs. $36,4 \%)$ a legutóbbi népszámlálási adatokkal csaknem megegyező megoszlási arányokat sikerült elérni [14]. Korábban elkezdett vizsgálatunk továbbfolytatásának az egyik legfontosabb indoka az volt, hogy a budapestiek aránya kevesebb volt a megfelelőnél [12]. 
A vizsgáltak életkori megoszlása egyenletes volt mindhárom vizsgált településfajtában, Budapesten kissé több fiatallal. A bevont személyek életkori csoportjainak aránya az 50. életévig 1-2\%-nál nem tért el jobban a népszámlálási adatoktól. E fölött 30\%-kal, az 55. év fölötti csoportokban viszont 50-80\%-kal voltak „túlreprezentálva” vizsgálati alanyaink. Ennek magyarázata az, hogy ők már szinte csak a háziorvosi rendelőkben megjelenő személyek voltak, míg a fiatalabb korosztályokban a közösségi színtereken bevontak jelentős arányt képviseltek. Ennek megfelelően a két vizsgált megbetegedés prevalenciája a hasonló korú, teljes populációban $46,4 \%$, a vizsgáltban $56,2 \%$ volt. Nem meglepő módon a hasi elhízott férfiaknál (>102 cm) a megbetegedések 48,8\%-ban fordultak elö, míg a csak veszélyesnek tartott haskörfogat esetén (94-102 cm) mindössze 25,6\%-ban.

Jelen felmérés csak a tényeket rögzíti, amelyeknek alapot kell szolgáltatni a nemcsak orvosi feladatot jelentő, hanem össztársadalmi figyelmet, a jelenleginél nagyobb politikai támogatást igénylő, egyre súlyosabb probléma megoldása irányába. Biztosítani kell a kollégák megfelelő (tovább)képzését, elsősorban az alapellátásban, és a müködőképes külföldi modellek hazai meghonosítását, megfelelő kutatási támogatás mellett [15-17].

Anyagi támogatás: A szerzők a közlemény alapját képező vizsgálattal kapcsolatban semmiféle anyagi támogatásban nem részesültek. Egyéb, az elhízással kapcsolatos kutatómunkájukért R. I. és S. J. az IGEN-TÁMOP 4.22.A-II/I KON-2012-003 projekt keretében kaptak támogatást.

Szerzői munkamegosztás: R. I.: A vizsgálat megtervezése, országos koordinációja, irodalomkutatás, szövegírás, végső szerkesztés. U. T.: Az adatbázisok kezelése, elemzése, statisztikai számítások. Sz. J.: A munkahelyi vizsgálatok koordinálása. T. P.: A budapesti vizsgálatok szervezése, adatgyújtése. M. Cs.: A kecskeméti és regionális vizsgálatok szervezése, adatgyüjtése. J. Z.: A debreceni és regionális vizsgálatok szervezése, adatgyüjtése. S. J.: Epidemiológiai elemzések, statisztikai számítások ellenőrzése, végső szerkesztése. A kézirat végleges változatát valamennyi szerző elolvasta és jóváhagyta.

Érdekeltségek: A szerzőknek nincsenek gyógyszeripari érdekeltségeik.

\section{Köszönetnyilvánítás}

A szerzők itt mondanak köszönetet az adatgyújtést önzetlenül végző orvoskollégáknak és segítőiknek.

\section{Irodalom}

[1] Bray, G. A.: Classification and evaluation of the overweight or obese patient. In: Bray, G. A., Bouchard, C. (eds.): Handbook of obesity. Clinical application. Third edition. Informa Healthcare, New York, 2008.
[2] Großschädl, F., Stronegger, W. J.: Regional trends in obesity and overweight among Austrian adults between 1973 and 2007. Wien. Klin. Wochenschr., 2012, 124(11-12), 363-369.

[3] Voss, J. D., Masuoka, P., Webber, B. J., et al.: Association of elevation, urbanization and ambient temperature with obesity prevalence in the United States. Int. J. Obes. (Lond.), 2013, 37(10), 1407-1412.

[4] Bíró, Gy. (ed.): First Hungarian representative nutrition survey (1985-1988). National Institute of Food Hygiene and Nutrition. [Az első magyarországi reprezentatív táplálkozási vizsgálat (1985-1988).] OÉTI, Budapest, 1992. [Hungarian]

[5] Zajkás, G., Biró, Gy.: Some data on the prevalence of obesity in Hungarian adult population between 1985-88 and 1992-94. Z. Ernährungswiss., 1998, 37(Suppl. 1), S134-S135.

[6] Balogh, S., Kékes, E., Császár, A.: Estimation of cardiovascular risk factors within primary care practices. The CORPRAX study. [A cardiovascularis rizikófaktorok felmérése háziorvosi praxisokban. A CORPRAX tanulmány.] Medicus Universalis, 2004, 37(1), 3-10. [Hungarian]

[7] Martos, É., Kovács, V. A., Bakacs, M., et al.: Hungarian diet and nutritional status survey - the OTAP2009 study. I. Nutritional status of the Hungarian population. [Országos Táplálkozás- és Tápláltsági Állapot Vizsgálat - OTÁP2009. I. A magyar lakosság tápláltsági állapota. Orv. Hetil., 2012, 153(26), 1023-1030. [Hungarian]

[8] Bényi, M., Kéki, Zs., Hangay, I., et al.: Obesity related increase in diseases in Hungary studied by the Health Interview Survey, 2009. [Elhízással összefüggő morbiditásnövekedés az Országos Lakossági Egészségfelméres alapján (2009).] Orv. Hetil., 2012, 153(20), 768-775. [Hungarian]

[9] Halmy, L., Simonyi, G., Csatai, T., et al.: Hungarian policemen study on the prevalence of obesity. Int. J. Obes., 2003, 227, S1S132.

[10] Global Health Observatory Data Repository. http://apps.who. int/gho/data/node.main.A897!lang=en

[11] Global Health Observatory Data Repository. http://apps.who. int/gho/data/node.main.A900!lang=en

[12] Rurik, I., Torzsa, P., Szidor, J., et al.: A public health threat in Hungary: Obesity, 2013. BMC Public Health, 2014, 14, 798.

[13] Jensen, M. D., Ryan, D. H., Apovian, C. M., et al.: 2013 AHA/ ACC/TOS guideline for the management of overweight and obesity in adults: A report of the American College of Cardiology/American Heart Association Task Force on Practice Guidelines and The Obesity Society. Circulation, 2014, 129(25 Suppl. 2), S102-S138.

[14] Hungarian Central Statistical Office: Census, 2011. [Központi Statisztikai Hivatal: Népszámlálás, 2011.] www.ksh.hu/nepszamlalas/tablak_teruleti_00 [Hungarian]

[15] Rurik, I., Torzsa, P., Ilyés, I., et al.: Primary care obesity management in Hungary: evaluation of the knowledge, practice and attitudes of family physicians. BMC Fam. Pract., 2013, 14, 156.

[16] Kovač Blaž, M., Švab, I.: A multidisciplinary approach to treating obesity in a community health centre. Zdr. Varst. (Slov. J. Public Health), 2015, 54(4), 252-258.

[17] Fülöp, P., Seres, I., Lörincz, H., et al.: Association of chemerin with oxidative stress, inflammation and classical adipokines in non-diabetic obese patients. J. Cell. Mol. Med., 2014, 18(7), 1313-1320.

(Rurik Imre dr., Debrecen, Móricz Zs. krt. 22., 4032 e-mail: Rurik.Imre@sph.unideb.hu) 